\title{
Three Essays on the Influence of Political Connections on Firm
} International Expansion Strategy

João Albino-Pimentel

Ph.D. awarded by HEC Paris, France (May 2016)

\section{BIG Question:}

'How do capabilities stemming from firms' non-market engagement influence their strategy and performance? Specifically, how do firm political connections impact international expansion strategy and performance?"

\section{Introduction}

Firms and governments are inextricably related. They, consequently, influence each other's decisions and performance. To deal with this interdependence and obtain the best possible policies for their business interests, it is thus natural that firms engage in politics. The literatures on non-market strategy and on corporate political activities have extensively analyzed how activities such as campaign donations and lobbying and more relational forms of political engagement, such political connections, affect firm performance. However, a consensus on the direction of such a relationship has not yet been reached. Indeed, some studies find that political engagement affects firm performance positively, while others find a negative or neutral effect (Faccio, 2006; Fisman, 2001; Sun, Mellahi, \& Wright, 2012). This suggests the need for a better understanding of the mechanisms through which firm political engagement-political connections in particular-might affect firm performance.

In my dissertation, I investigate how capabilities stemming from a firm's political engagement influence that firm's international strategy and performance. More specifically, I explain and empirically show how a firm's political connections- that is, the relationships it holds with political and government authorities in its country of origin -impact its international expansion strategy and performance.

My main proposition is that investigating how firm political connections affect strategy choices helps shed light on the ac- tual mechanisms through which such connections might lead to performance heterogeneity. Based on my review of the literature, I identified three main issues that appear to explain the mixed results in prior work. The first issue is that firms vary in their capability to use political connections to influence political actors and to mobilize government resources. In other words, firms are possibly heterogeneous with regards to their political capabilities and this heterogeneity may generate distinct performance outcomes (Baron \& Hall, 2003; Bonardi, 2011; Bonardi, Holburn, \& Bergh, 2006; Lester et al., 2008). The second issue is that this stream of research still devotes little attention to the fact that different types of political connections operate through different channels and may influence firms through distinct mechanisms. The third issue is that a firm's political connections may have their most meaningful effect on that firm's strategy, and only affect its performance indirectly (Siegel, 2007). Accordingly, I argue that different types of political connections are the basis of heterogeneous capabilities, which, in turn, influence a firm's strategic moves, such as international expansion.

My dissertation addresses all the three issues in the literature throughout three empirical studies. I put forth that assessing a firm's political capabilities, which should be more stable over time and reflect the firm's effectiveness in attaining its objectives from the government, is a way to address the first issue. I further argue that focusing on political connections is an appropriate approach to assess political capabilities. In comparison to indirect or transactional political relations (Hillman \& Hitt, 1999), which are generated through actions such as campaign donations and lobbying, relational political connections are more long-lasting and arguably effective in generating political capabilities (Bonardi, 2011; Faccio, 2006). Nonetheless, studies on the effects of political connections on firm-level outcomes have primarily emphasized their impact on firm performance (Faccio, 2006; Fisman, 2001), and, thus, produced limited documentation of their influence on firm strategy. 
To address the second issue underlying the lack of consensus in the literature on the effects of political connections, it is important to account for the various types of political connections and how they may operate differently. Prior research has documented the relevance of numerous types of such relational political connections separately. I put forth that these political connections operate differently in influencing firm strategy and thus generate contrasting performance implications.

Finally, to address the third issue, I argue that it is critical to understand whether and how firms with political connections make distinct strategic moves relative to firms without political connections, because performance differentials may stem from this heterogeneity in strategy. In particular, examining the influence of political connections on highly politically-entrenched decisions, where this influence might be more easily observable and more meaningful, can contribute immensely to advancing the literature. International expansion strategy not only allows me to observe such an effect, as it is indeed a type of strategy with deep political entrenchment, but also allows me to analyze whether the benefits (or liabilities) stemming from political connections are geographically constrained. When investing internationally, firms have to deal with heterogeneous political contexts and face more uncertainty, including political uncertainty. As a consequence, international expansion strategy and performance tend to exhibit a deeply entrenched political nature and, therefore, constitute an ideal research setting to investigate the impact of political connections on firms' strategies.

The dissertation is composed of three essays, each contributing to address part of the puzzle regarding how political connections affect a firm's international expansion strategy and performance. In the first essay, I examine the role of political connections as a moderator of the relationship between homehost ties and international strategy in a sample of greenfield investments in manufacturing undertaken by firms from eleven home countries. In the second and third essays, I rely on an original hand-collected dataset that includes information on various political connections enjoyed by the largest French firms. In the second essay, I investigate the role of different types of political connections on a firm's international investments amount and risk profile. Finally, in the third essay, I analyze how political connections influence the speed with which firms secure funding and complete development of their project finance-based investments, two highly politically-entrenched performance indicators.

\section{Essay 1: The Influence of Foreign Affairs and Firm Political Influence on the Location Choice of International Invest- ments}

In the first essay, I investigate the role of political capabilities as moderators of the relationship between Bilateral Investment Treaties (BITs), a dimension of home-host ties, and firms' choice of location of international investments. I hypothesize that a firm is more likely to invest in a potential host nation when the firm's home country has a BIT with that potential host nation. More importantly, I predict that BITs are more meaningful for firms without the ability to use alternative means to protect their investments, particularly firms without political connections in their home country or firms without enough political clout. In other words, I predict that politically-connected and politically-savvy firms enjoy a competitive edge regarding their ability to invest in places where other firms shy away from investing in. Examining international greenfield investments in manufacturing carried out by firms from eleven home countries between 2003 and 2010, I find support for my predictions. BITs indeed appear to provide a mechanism that allows governments to credibly commit to foreign investors, as the existence of a ratified BIT between home and host countries positively affects the likelihood of investment. More importantly, such a suppranational institutional arrangement is especially meaningful for investing firms that do not have strong political connections in their home nation and that do not have enough political clout. That is, politically-connected and politically-savvy firms choose the location of their international investments independently of BITs.

\section{Essay 2: The French Connection: The Influence of Political Connections on International Expansion Strategy}

In the second essay, I examine the effects of political connections on international expansion strategy in more detail. I analyze how three types of political connections-government experience-based, common education-based, and friendship-based political connections-influence both the amount and the level of exposure to expropriation risk of the firm's international investments in a given period of time. I propose three ways through which political connections should positively impact a firm's international expansion strategy: (i) privileged information and knowledge, (ii) influence and (iii) lower investment costs. Furthermore, I argue that friendship-based political connections will be more valuable when the firm's decision makers have a personal friend or family member that enjoys more (rather than less) power in the home country's government. Accordingly, an increase in the value of those political connections should also intensify their influence on a firm's international expansion strategy. Using data on the international investments made by the largest French firms during the 2003-2012 period, I find empirical support for the main predictions. Politically-connected firms engage in distinct international expansion strategies relative to non-politically-connected firms. This heterogeneity is contingent on the type of political connections, with political connections based on friendship ties and on common educational background being the most meaningful ones in explaining the amount and the level of exposure to expropriation risk of a firm's international investments, respectively. Finally, I find that the election of Nicolas Sarkozy as the president of France generated significant effects on the strategy of firms connected to him through friendship ties. Specifically, firms enjoying friendship ties with 
Sarkozy spent significantly more in their international investments after the 2007 election.

\section{Essay 3: The Staying Hand: Political Connections and Speed of Financing in Investment Projects}

In the third essay, I examine the influence of political connections on a highly politically-entrenched type of firm performance: the speed of financing of a firm's investment projects. Despite their widespread use in large infrastructure projects around the world, there is a stark dearth of research on project finance-based (PF) investments (Vaaler, 2008), especially regarding a firm's capabilities to undertake successful PF investments. Speed is a notably relevant indicator of project performance, as the time required to obtain funding and then to complete project development entails substantial costs for both sponsor firms and other stakeholders. I put forth that political connections operate as a mechanism to reduce PF investments risks and should, thus, positively influence PF investments speed. However, political connections should be relevant only when in combination with other project, sponsor, and location attributes that together determine the overall riskiness of a particular project. I further maintain that political connections, depending on other project attributes, might even slow down the project, thus becoming a liability for project speed. Finally, I allow distinct types of political connections to associate with different outcomes. I use fuzzy sets methods to empirically investigate these propositions on a sample of PF investments sponsored by the largest firms listed in the Paris stock exchange, during the 2003-2012 period. These projects are concentrated in infrastructure industries such as power distribution, transportation, oil and gas, and water treatment and distribution. My findings provide interesting insights and advances the understanding on the various pathways firms can follow to speed up or to avoid delays in their PF investments.

\section{Conclusion}

With my dissertation I make substantial contributions to the literature on global and non-market strategy. First, my results advance knowledge on how firms can benefit from their activities vis-à-vis the government in the home country to develop political capabilities that become useful in foreign countries, particularly those characterized by a higher risk of expropriation (Delios \& Henisz, 2003; García-Canal \& Guillén, 2008; Holburn \& Zelner, 2010). My analysis goes beyond the idea of firms from a same home country sharing the same level of political capabilities, but proposes and empirically analyzes the effect of heterogeneity in political connections among firms from a same home country (Fisman, 2001; Faccio, 2006). I also add to the literature on political connections, by comparing the effects of three types of political connections on firms' strategy and by showing that different types of political connections have distinct effects on international expansion strategy and performance.
Furthermore, I make a contribution to the stream of research on the effects of inter-governmental ties on FDI flows, by analyzing firm-level data and by focusing on BITs. More importantly, I show that these organizations, and the underlying credible commitments they allow host countries to make, are only meaningful antecedents of international strategy for firms not enjoying strong ties with government authorities in the home country. In addition, across the three essays, my findings rely on extremely rich data about various types of political connections and international expansion strategies by firms originating in several countries.

\section{References}

Baron, D. P., \& Hall, P. 2003. Business and its Environment. Prentice Hall Englewood Cliffs, NJ.

Bonardi, J.-P. 2011 . Corporate political resources and the resource-based view of the firm. Strategic Organization, 9(3): 247-255.

Bonardi, J.-P., Holburn, G. L., \& Bergh, R. G. V. 2006. Nonmarket strategy performance: Evidence from US electric utilities. Academy of Management Journal, 49(6): 1209-1228.

Delios, A., \& Henisz, W. J. 2003. Political hazards, experience, and sequential entry strategies: The international expansion of Japanese firms, 1980-1998. Strategic Management Journal, 24(1 1): $1153-1164$

Faccio, M. 2006. Politically connected firms. The American Economic Review, 96(1): 369-386.

Fisman, R. 2001 . Estimating the value of political connections. American Economic Review, 91 (4): 1095-1102.

García-Canal, E., \& Guillén, M. F. 2008. Risk and the strategy of foreign location choice in regulated industries. Strategic Management Journal, 29(10): 1097-1115.

Hillman, A. J., \& Hitt, M. A. 1999. Corporate political strategy formulation: A model of approach, participation, and strategy decisions. Academy of Management Review, 24(4): 825-842.

Holburn, G. L., \& Zelner, B. A. 2010. Political capabilities, policy risk, and international investment strategy: evidence from the global electric power generation industry. Strategic Management Journal, 31 (12): 1290-1315.

Lester, R. H., Hillman, A., Zardkoohi, A., \& Cannella, A. A. 2008. Former government officials as outside directors: The role of human and social capital. Academy of Management Journal, 51 (5): 999-1013.

Siegel, J. 2007. Contingent political capital and international alliances: Evidence from South Korea. Administrative Science Quarterly, 52(4): 621-666.

Sun, P., Mellahi, K., \& Wright, M. 2012. The contingent value of corporate political ties. The Academy of Management Perspectives, 26(3): 68-82.

Vaaler, P. M. 2008. How do MNCs vote in developing country elections? Academy of Management Journal, 51 (1): 21-43. 
Joao Albino-Pimentel (joao.albino-pimentel@moore.sc.edu) is an assistant professor at the Moore School of Business at the University of South Carolina. His research interests revolve around non-market and international strategy. Joao's research has been recognized with various awards and nominations by AIB, EIBA, SMS and AOM. Joao holds degrees in economics and in management from the University of Sao Paulo, a master's in business economics from the University of Grenoble and a Ph.D. in Strategy from HEC Paris. 